Bangladesh J. Zool. 40(2): 175-181, 2012

\title{
PEDICULOSIS AMONG THE CHILDREN OF DIFFERENT SOCIAL STATUS IN DHAKA
}

\author{
Mt. Tahmina Karim, Sharmin Musa* and Hamida Khanum* \\ Department of Zoology, University of Dhaka, Dhaka-1000, Bangladesh
}

\begin{abstract}
The prevalence of head lice (Pediculus humanus capitis) infestation was studied among the children (1 to 7 years) in the area of Mirpur Bihari Camp, Mirpur-11, Dhaka. A total of 300 children was examined from February 2011 to January 2012 and $59.67 \%$ prevalence of head lice infestation was observed. The prevalence of pediculosis was significantly higher $(\mathrm{p}<0.05)$ in seven years aged children and the prevalence was significantly $(\mathrm{p}<0.05)$ higher in girls $(72.62 \%)$ than boys $(43.18 \%)$. School going children had higher $(\mathrm{p}<0.05)$ prevalence compared to preschool group. According to socioeconomic status, head lice infestation occurred almost equally in all social classes.
\end{abstract}

Key words: Pediculosis, prevalence, children, socioeconomic status.

\section{INTRODUCTION}

Pediculosis is one of the most common contagious childhood diseases. It is an infestation of the head with Pediculus humanus var capitis (Cumbescot 2000). These are obligate, blood-feeding human ectoparasites. They are connected to human hosts during all life stages with physical head-to-head contact as the main route of transmission (Heukelbach 2010). Head lice are widespread throughout the world, with varied prevalence across countries from less than $1 \%$ to well above $50 \%$ (Falagas et al. 2008). The cause of this variation may be due to several factors including the number of head-to-head contacts, diagnostic techniques, eradication methods, pesticide resistance, knowledge regarding head lice prevention and perception of pediculosis as a health problem etc. An infestation can persist for a long time if inspection and treatment are not synchronized (Ibarra et al. 2009).

The insects are harbored on the scalp and may lead to severe itching and hemorrhage. The intense scratching may cause excoriations, secondary bacterial infection, oedema and adenopathy. Also, they may transmit serious epidemic diseases, such as epidemic typhus, trench fever and relapsing fever (Benenson 1998). Pediculosis also has social and psychological impact on infested children and their parents. Such an impact leads to restraint in seeking advice from healthcare providers, which leads to underestimation of the magnitude of the problem. Juranek (2001) asserted that outbreaks of pediculosis generally takes place during periods of economic crisis or wars, as happening in the second world war, pediculosis was rare in the post second world war period but since 1970s it had increased considerably. Sinniah et al. (2003), Sarov et al. (2004) 
and Chunge (2004) reported that sex influences head lice infestation with higher prevalence in girls than boys. But, lack of significant association between sex and head lice infestation was reported in three countries, Kenya, Saudi Arabia and Israel (Chunge 2004).

Ramussen (2004) highlighted that lice spread more rapidly in large families living in crowded conditions where bed-sharing and poor hygiene exist. While, Tampling et al. (1991) reported that most children with head lice infestation are the children of working parents. Significant relationships between head lice infestation and crowding were reported by many workers (Ray and Tandon 2000, Sinniah et al. 2003 and Sarov et al. 2004).

Higher prevalence of pediculosis has been relatively observed in girls than boys (Catala et al. 2005, Motovali-Emami et al. 2008 and Toloza et al. 2009). Social interactions may explain these differences (Heukelbach 2010), as contacts between boys are assumed to be more brief than between girls, who have more prolonged and closer head contacts (Speare and Buettner 1999). Although socioeconomic status seems to be an indicator of the magnitude of lice infestation, more specific determinants are the dynamic processes of hygienic status and overcrowding (Falagas et al. 2008).

The higher prevalence of head lice is observed in elementary school children than in other age groups (Roberts 2002, Leung et al. 2005). Changes in social interactions with age can be an important element explaining such a pattern. Mossong et al. (2008) found that contact rates were higher among school children compared to other age groups in all European countries investigated. In Pediculus there are always three larval instars, and it is not difficult to distinguish them. But, the second and third instars are less easy to separate (Buxton 1940).

Although, there are report on infestation and epidemiology of pediculosis (Rios et al. 2008), the information on factor, no recent and organized work so far had been done in Bangladesh. In the country, lice infestation is also a major public annoying problem. Here treatment facilities are less and there is no wide spread study in this regard.

The objective of the study was to observe the prevalence of pediculosis among children in relation to age, sex, educational status, and social and family status of people.

\section{MATERIAL AND METHODS}

A cross sectional study was carried out during February 2011 through January 2012 among the children up to seven years in Mirpur Bihari Camp in Mirpur-11, Dhaka. A total of three hundred children was examined for the 
infestation of head lice. Head lice infestation was detected by examining the scalp and hairs of the children for the presence of adult lice, nymphs or viable nits in naked eyes or with the aid of a magnifying glass or running a comb through the child's hair. Later, the collected lice were identified under a microscope.

A structured questionnaire was selected for data collection and a completely randomized sampling procedure was followed for the study. The children were categorized into preschool (1 to 4 years) and school going children group. The school going children again divided into grade- 1 (5 years), grade- 2 (6 years) and grade-3 (7 years).

Overcrowding assessment was carried out by the number of family members, and three types of family were found large ( $>7$ members), medium and small. The questionnaire was filled up for each child and their families through face to face interviewing.

Prevalence rate was showed by calculating the percentage of infestation and result was analyzed statistically. Statistical analysis was carried out by using Statistical Package for Social Science (SPSS) using F-test.

\section{RESULTS AND DISCUSSION}

In the present study, a total of 300 children was examined, of them 179 (59.67\%) were found to be infested with the louse, P. h. capitis. In Australia 33\% infestation (Speare et al. 1999) and in Argentina 56.8\% (Milano et al. 2007), were reported. However, much lower rate of infestation, viz. 10.7\% was recorded among primary school children of Malaysia (Sinniah et al. 2003) and 6.85\% among school children in Iran (Nazari and Saidijam 2007). These variations in infestation rate might be due to the social status and personal hygiene practices of people and environmental factors.

Age of the individuals had an effect on the prevalence of pediculosis in humans. In the present study, prevalence rate increased according to the increase of age group. The prevalence was significantly $(\mathrm{p}<0.05)$ higher in 7 years group $(72.15 \%)$ of child than that in other child groups (Table 1). The majority of the infested children was school going. Out of 141 preschool children, 66 (46.81\%) were infested by parasites. Within school going children, grade-1 (five yrs aged) was 45, among them 31 (68.89\%) were infested; Grade-2 (six yrs) was 35, among them 25 (71.43\%) were infested; Grade-3 (seven yrs) were 79 , and $57(72.15 \%)$ was infested and result was significant $(\mathrm{p}<0.05)$ (Table 1$)$.

The age of the children had a significant $(p<0.05)$ effect on lice infestation. The children of seven years $(72.15 \%)$ were the most susceptible group (Table 1 ). Lapreere et al. (2005) reported that head lice are very common and mainly affect 
the children aged 3 to 12 years in Belgium. Rupes et al. (2006) found that $14.1 \%$ of the school going children aged between six and 15 years had active pediculosis. It is very difficult to explain exactly the reasons behind the frequent occurrence of the infestation among the children. However, it may be speculated that school going children are more prone to lice infestation. Differences in the head lice distribution rates between age groups six and 13 years are supported by many studies. It seems that younger groups are dependent on parents and guardians for combing and washing or cleaning their hair (Alempour-Salemi et al. 2003).

Table 1. Prevalence of pediculosis according to age and educational status of the children of Mirpur area, Dhaka from February 2001 to January 2012.

\begin{tabular}{|c|c|c|c|c|c|c|c|}
\hline $\begin{array}{l}\text { Age } \\
\text { Groups } \\
\text { (yrs) }\end{array}$ & $\begin{array}{l}\text { Numbe of } \\
\text { child } \\
\text { examined }\end{array}$ & $\begin{array}{l}\text { No. of } \\
\text { infested } \\
\text { child }\end{array}$ & $\begin{array}{l}\text { Prevalence } \\
\text { of infested } \\
\text { child }\end{array}$ & $\begin{array}{l}\text { Educational } \\
\text { status of the } \\
\text { children }\end{array}$ & $\begin{array}{c}\text { No. of } \\
\text { child } \\
\text { examined }\end{array}$ & $\begin{array}{l}\text { No. of } \\
\text { infested } \\
\text { child }\end{array}$ & $\begin{array}{c}\text { Prevalence } \\
\text { of infested } \\
\text { child }\end{array}$ \\
\hline $1 \mathrm{yrs}$ & 21 & 6 & 28.57 & Preschool (1-4) & 141 & 66 & 46.81 \\
\hline $2 \mathrm{yrs}$ & 34 & 15 & 44.12 & & & & \\
\hline $3 \mathrm{yrs}$ & 40 & 17 & 42.5 & & & & \\
\hline 4 yrs & 46 & 28 & 60.87 & $\begin{array}{l}\text { School going } \\
\text { children (5-8) }\end{array}$ & & & \\
\hline $5 \mathrm{yrs}$ & 45 & 31 & 68.89 & Grade-1 (5yrs) & 45 & 31 & 68.89 \\
\hline $6 \mathrm{yrs}$ & 35 & 25 & 71.43 & Grade-2 (6yrs) & 35 & 25 & 71.43 \\
\hline $7 \mathrm{yrs}$ & 79 & 57 & 72.15 & Grade-3 (7yrs) & 79 & 57 & 72.15 \\
\hline Total & 300 & 179 & & Total & 300 & 179 & \\
\hline
\end{tabular}

The educational status of the children greatly influenced the rate of lice infestation. The largest proportion of the infested children $(72.15 \%)$ belonged to the grade-3, seven years children (Table 1). It might be due to the fact that seven years children have more interactive social life. This result corroborates those of Roberts (2002), Leung et al. (2005) and Mossong et al. (2008).

It was detected that the prevalence of pediculosis was significantly $(\mathrm{p}<0.05)$ higher in girls $(72.62 \%)$ than in boys $(43.18 \%)$ (Table 2$)$. This gender-related behavioural differences observed earlier by Sinniah et al. (2003), Alempoursalemi et al. (2003), Sarov et al. (2004), Catala et al. (2005), Motavali et al. (2008) and Toloza et al. (2009). Close contact between the heads of boys tends to occur briefly in rough and tumble play, while for girls close head contact is often more intimate and prolonged (Speare and Buettner 1999).

Table 2. The prevalence of pediculosis according to the sex of the children of Mirpur area, Dhaka from February 2001 to January 2012.

\begin{tabular}{cccc}
\hline Sex of the Child & $\begin{array}{c}\text { No. of child } \\
\text { examined }\end{array}$ & $\begin{array}{c}\text { No. of infested } \\
\text { child }\end{array}$ & $\begin{array}{c}\text { Prevalence of infested } \\
\text { child }\end{array}$ \\
\hline Boys & 132 & 57 & 43.18 \\
Girls & 168 & 122 & 72.62 \\
\hline Total & $\mathbf{3 0 0}$ & $\mathbf{1 7 9}$ & \\
\hline
\end{tabular}


The social status and living standard of children was not statistically significant $(\mathrm{p}>0.05)$, but the prevalence was highest in lower class people (68.24\%) followed by middle class $(58.70 \%)$ and the lowest was recorded in upper class people (51.95\%) (Table 3).

Table 3. The prevalence of pediculosis in different social status of the children of Mirpur area, Dhaka from February 2001 to January 2012.

\begin{tabular}{lccc}
\hline Socioeconomic status & $\begin{array}{c}\text { No. of child } \\
\text { examined }\end{array}$ & $\begin{array}{c}\text { No. of infested } \\
\text { child }\end{array}$ & $\begin{array}{c}\text { Prevalence of infested } \\
\text { child }\end{array}$ \\
\hline Lower class $(<5000)$ & 85 & 58 & 68.24 \\
Middle class $(5000-10,000)$ & 138 & 81 & 58.70 \\
Upper class $(10,000-16,000)$ & 77 & 40 & 51.95 \\
\hline Total & $\mathbf{3 0 0}$ & $\mathbf{1 7 9}$ & \\
\hline
\end{tabular}

Lonc and Okulewiez (2000) showed that there is a direct relationship between the high incidence of pediculosis with low standard ecological indices and social economic setting of communities. But, the head lice can infest all classes of children during their play times.

Most of the children were from large families and the infestation rate of parasites among three family groups (small, medium, large) was 42.68, 52.04 and $77.50 \%$, respectively (Table 4). The result was statistically significant $(\mathrm{p}<0.05)$ indicating that in large family, infestation rate was higher because of large number of family members who shared their personal items and bed. Ray and Tandon (2000), Sarov et al. (2004), and Ramussen (2004) also opined that overcrowding in a room may account for easy transmission of pediculosis. The risk of pediculosis increased with the number of household members (MotovaliEmami et al. 2008 and Soultana et al. 2009).

Table 4. The prevalence of pediculosis by family size of the children of Mirpur area, Dhaka from February 2001 to January 2012.

\begin{tabular}{lccc}
\hline Family size & No. of child examined & No. of infested child & Prevalence of infested child \\
\hline Small & 82 & 35 & 42.68 \\
Medium & 98 & 51 & 52.04 \\
Large & 120 & 93 & 77.5 \\
\hline Total & $\mathbf{3 0 0}$ & $\mathbf{1 7 9}$ & \\
\hline
\end{tabular}

Among 300 children, $23.53 \%$ was infested with lice that had very short hair, $68.12 \%$ among short hair, 90.00\% among medium size hair and 92\% among long hair children (Table 5). So, the length of hair had an effect on the prevalence of pediculosis. 
Table 5. The prevalence of pediculosis based on hair length of the children of Mirpur area, Dhaka from February 2001 to January 2012.

\begin{tabular}{cccc}
\hline Length of hair & No. of child examined & No. of infested child & Prevalence of infested child \\
\hline Very Short & 85 & 20 & 23.53 \\
Short & 160 & 109 & 68.12 \\
Medium & 30 & 27 & 90.00 \\
Long & 25 & 23 & 92 \\
\hline Total & $\mathbf{3 0 0}$ & $\mathbf{1 7 9}$ & \\
\hline
\end{tabular}

This study provides some important factors of the epidemiology of pediculosis in a group of people in Bangladesh. The findings of this study suggest that parents need to involve themselves more in ensuring personal hygiene for their children. Pediculosis affects all races and social classes; it is frequent in school going children, mostly present in girls and common in lower status people.

\section{LITERATURE CITED}

ALEMPOUR-SALEMI, J., SHAYEGHI, N., ZERAATI, H., AKBARZADEH, K., BASSERI, H., EBRAHIMI, B. and RAFINEJAD, J. 2003. Some Aspects of Head Lice Infestation in Iranshahr Area (Southeast of Iran). Iranian J. Publ. Helth. 32(3): 60-63.

BENENSON, A.S. 1998. Control of Communicable diseases in man (24th Ed.). American Public Health Association, Washington, DC. pp. 105-125.

BUXTON, P.A. 1940. Studies on populations of head-lice (Pediculus humanus capitis: Anoplura). III. Material from South India. Parasitology 32: 296-302.

CATALA, S., JUNCO, L. and VAPORAKY, R. 2005. Pediculus capitis infestation according to sex and social factors in Argentina. Revista de Saude Publica 39: 438-443.

CHUNGE, R.N. 2004. A study of head lice among primary school children in Kenya. Trans. Res. Soc. Trop. Med. Hyg. 92: 86-90.

CUMBESCOT, C. 2000. Current epidemiology of Pediculus capitis. Bull. Acad. Nat.l Med. 181: 331335.

FALAGAS, M.E., MATTHAIOU, D.K., RAFAILIDIS, P.I., PANOS, G. and PAPPAS, G. 2008. Worldwide prevalence of head lice. Emerging Infectious Diseases 14: 1493-1494.

HEUKELBACH, J. 2010. Management and Control of Head Lice Infestations. UNI-MED Verlag AG; Bremen, Germany, pp. 65-117.

IBARRA, J., FRY, F., WICKENDEN, C., JENNER, M. and FRANKS, A. 2009. The impact of welldeveloped preventative strategies on the eradication of head lice. Perspectives in Public Health 129: $165-173$.

JURANEK, D.D. 2001. Pediculosis and Scabicides: Handbook of drug therapy London; Saunders publishers

MUMCUOGLY, K.Y., KLAUS, S. and KAFKA, D. 1994. Clinical Observations Related to head lice infestation. J. Am. Acad. Dermatol. 51: 315-319. 
LAPEERE, H., BROCHEZ, L., HAEGHEN, Y., MABILDE, C., STICHELE, R., LEYBAERT, L. and NAEYAERT, J.M. 2005. Method to measure force required to remove Pediculus humanus capitis (Phthiraptera: Pediculidae) eggs from human hair. J. Med. Entomol. 42(1): 89-93.

LEUNG, A.K., FONG, J.H. and PINTO-ROJAS, A. 2005. Pediculosis capitis. J. Ped. Health Care 19: 369-373.

LONC, E. and OKULEWICZ, A. 2000. Scabies and head-lice infestations in different environmental conditions of Lower Silesia, Poland. J. Parasitol. 86(1): 170-171.

MILANO, A.M.F., OSCHEROV, E.B. and LEGAL, A.Z. 2007. Pediculosis and other parasitosis in a northeast Argentine children population. Parasitologia Latinoamericana 62(1/2): 83-88.

MOSSONG, J., HENS, N., JIT, M., BEUTELS, P., AURANEN, K., MIKOLAJCZYK, R., MASSARI, M., SALMASO, S., TOMBA, G.S., WALLINGA, J., HEIJNE, J., SADKOWSKA-TODYS, M., ROSINSKA, M. and EDMUNDS, W.J. 2008. Social contacts and mixing patterns relevant to the spread of infectious diseases. Plos Medicin 5: 381-391.

MOTOVALI-EMAMI, M., AFLATOONIAN, M.R., FEKRI, A. and YAZDI, M. 2008. Epidemiological aspects of Pediculosis capitis and treatment evaluation in primary-school children in Iran. Pakistan J. Biol. Sci. 11: 260-264.

NAZARI, M. and SAIDIJAM, M. 2007. Pediculus capitis infestation according to sex and social factors in Hamedan-Iran. Pakistan J. Biol. Sci. 10: 3473-3475.

RAMUSSEN, J.E. 2004. Pediculosis and the pediatrician, Pediat. Dermatol. 6: 172-177.

RIOS, S. M., FERNÁNDEZ, J.A., RIVAS, F., SÁENZ, M.L. and MONCADA, L.I. 2008. Pediculosis prevalence and associated risk factors in a nursery school, Bogotá, Colombia. Biomedica 28(2): 245-251.

ROBERTS, R.J. 2002. Clinical practice. Head lice. New England J. Med. 346: 1645-1650.

ROY, B. and TANDON, V. 2000. Louse infestation in human populations in Shillong. Indian Hlth. Hyg. 19: 56-60.

RUPES, V., VLCKOVA, J., MAZANEK, L., CHMELA, J. and LEDVINKA, J. 2006. Pediatric head lice: taxonomy, incidence, resistance, delousing. J. Epidemiol. Microbiol. Immunol. 55: 112-119.

SAROV, B., NEUMAN, L. and HERMAN, Y. 2004. Evaluation of an intervention programme for head lice infestation in school children. Ped. Infest. Dis. J. 12: 243-245.

SINNIAH, B., SINNAH, D. and REJESWARI, B. 2003. Epidemiology and control of human head louse in Malaysia. Trop. Geograph. Med. 35: 357-362.

SOULTANA, V., EUTHUMIA, P., ANTONIOS, M. and ANGELIKI, R.S. 2009. Prevalence of pediculosis capitis among schoolchildren in Greece and risk factors: A questionnaire survey. Ped. Dermatol. 26: 701-705.

SPEARE, R. and BUETTNER, P.G. 1999. Head lice in pupils of a primary school in Australia and implications for control. Int. J. Dermatol. 38: 285-290.

TAMPLING, M., NASH, J. and ALMOND, R. 1991. How to recognize and manage pediculosis reactions. Oxford University press, London. pp. 210-236.

TOlOZA, A., VASsenA, C., GAllardo, A., GONZAlEZ-Audino, P. and PiCOllO, M.I. 2009. Epidemiology of Pediculosis capitis in elementary schools of Buenos Aires, Argentina. Parasit. Res. 104: 1295-1298. 